\title{
Influence of Different Irrigation and Potassium Levels on Water-Use- Efficiency of Potato in Calcareous Soil
}

\author{
Mrityunjay Choubey ${ }^{1}$, Amit Kumar Pandey ${ }^{2 *}$ and Ashutosh Singh ${ }^{2}$ \\ ${ }^{1}$ Dr. Rajendra Prasad Central Agricultural University, Pusa, Samastipur-848 125, Bihar, India \\ ${ }^{2}$ Department of Soil Science and Agricultural Chemistry, Bihar Agricultural University, Sabour, \\ Bhagalpur-813 210, Bihar, India \\ *Corresponding author
}

\section{A B S T R A C T}

\begin{tabular}{|l|}
\hline Ke y w o r d s \\
Water use \\
efficiency, Potato, \\
$\begin{array}{l}\text { Irrigation level, } \\
\text { Potassium level, } \\
\text { Calcareous soil. }\end{array}$ \\
\hline Article Info \\
\hline $\begin{array}{l}\text { Accepted: } \\
\text { 28 August } 2017 \\
\text { Available Online: } \\
\text { 10 September } 2017\end{array}$ \\
\hline
\end{tabular}

The field experiment was conducted during the rabi season of 2005-2006 in Pusa Farm of Rajendra Agricultural University, Bihar in split plot design with sixteen treatment combinations consisting of four levels of irrigation and four levels of potash. Irrigation treatments were given after a common irrigation at 15 days after planting and $6 \mathrm{~cm}$ irrigation water was applied in each irrigations. Potato variety "Rajendra ALU- 3" was taken for present investigation. Total water requirement of $\mathrm{I}_{3}\left(1.0 \mathrm{IW} / \mathrm{CPE}\right.$ ratio) and $\mathrm{I}_{4}$ (1.2IW/CPE ratio) levels of irrigation was higher than $\mathrm{I}_{1}$ (0.6 IW/CPE ratio) and $\mathrm{I}_{2}(0.8$ IW/CPE ratio) levels of irrigation. The difference in water requirement between $\mathrm{I}_{3}(1.0$ IW/CPE ratio) and $\mathrm{I}_{4}$ (1.2IW/CPE ratio) was not prominent because both these levels received three irrigation each. Likewise differences in between $\mathrm{I}_{3}$ and $\mathrm{I}_{4}$ were not prominent because both $I_{3}$ and $I_{4}$ irrigation levels received two irrigations. The water requirement was almost the same due to different levels of potassium. Significantly higher water use efficiency was in the treatment $\mathrm{I}_{2}\left(0.8 \mathrm{IW} / \mathrm{CPE}\right.$ ratio). Potassium level $\mathrm{K}_{2}\left(\mathrm{~K}_{2} \mathrm{O}\right.$ $100 \mathrm{~kg} \mathrm{ha}^{-1}$ ) also record significant highest water use efficiency.

\section{Introduction}

Irrigation water is one of the costliest inputs used in crop cultivation. The primary attention centers round judicious use of irrigation water and improving water use efficiency to the highest possible limit. Thus, it is highly imperative to quantify "when and how much" irrigation should be given to harness optimum water use efficiency. Khalak and Kumaraswamy (1992) observed that the irrigation water given at frequent interval and in small quantity resulted in the improvement of growth attributes, dry matter accumulation and tuber yield in potato. Hukkeri and Sharma, 1979 concluded that potato could be subjected intermittently to mild stress once each at stolonization, early tuberization and tubes development which saved 30 percent of irrigation water without affecting the yield adversely, resulting in 33 to 41 percent higher production efficiency or irrigation water.

Potassium imports winter hardiness, develops disease and drought resistance, regulate stomatal movement and improve water use efficiency. Water stress causes a sharp increase in the concentration of abscisic acid in leaves and plant was supplied with $\mathrm{K}$ are associated with lower level of abscisic acid. 
Thus, it is indicated that the response to potassium in limiting the soil moisture level may improve water use efficiency are thereby maintain crop yield (Hsiao, 1973). The efficiency of irrigation is enhanced by potassium and vice-versa showing an interaction effect between them.

In brief, the application of irrigation and potassium in optimum dose at proper time plays a very significant effect on overall production of potato.

\section{Materials and Methods}

The field experiment was conducted during the rabi season of 2005-2006 at Pusa Farm of Rajendra Agricultural University. The details of the materials used and method adopted for carrying out the present study are described as below. The experimental site is located at $25^{\circ} 59^{\prime}$ North latitude and $85^{\circ} 48^{\prime}$ East longitude with an altitude of 52.92 meters above mean sea level (Table 1). The climate of the experimental area is sub-tropical with a mean annual precipitation of $1270 \mathrm{~mm}$ and mean annual temperature of $25.3^{\circ} \mathrm{C}$. The experiment was laid out in a thrice replicated split plot design having four levels of irrigation viz., 0.6, 0.8, 1.0 and 1.2 IW/CPE ratio in the main plot four levels of potassium viz., no potassium, 50, 100, and $150 \mathrm{~kg} \mathrm{~K}_{2} \mathrm{O}$ ha $^{-1}$ in sub-plot.

Irrigation treatments were given after a common irrigation at 15 days after planting and $6 \mathrm{~cm}$ irrigation water was applied in each irrigation. The quantity of irrigation water required in each plot was measured by Parashall Fume having a throat width of 7.5 $\mathrm{cm}$ installed at the head of the experimental plot. Weather conditions during the crop season are presented in table 2. The total amounts of water applied under different treatment are present table 3. Water requirement and water use efficiency were calculated using the following formula

$$
\begin{aligned}
& \text { Water requirement }(\mathrm{cm})=\mathrm{IR}+\mathrm{ER}+ \\
& \mathrm{n} \\
& {\left[\Sigma \frac{M b i-M e i}{100}\right] \times \text { BDi x Di }}
\end{aligned}
$$

Where,

$\mathrm{IR}=$ Amount of irrigation water applied $(\mathrm{cm})$

$\mathrm{ER}=$ Effective rainfall during the season $(\mathrm{cm})$

$\mathrm{n}=$ Number of soil layer considered level in root zone depth $\mathrm{D}$

Mbi $=$ Soil moisture percentage at the start of season in the $i^{\text {th }}$ layer

Mei $=$ Soil moisture percentage at the end of season in the $i^{\text {th }}$ layer

$\mathrm{BDi}=$ Soil bulk density in the $\mathrm{i}^{\text {th }}$ level $\left(\mathrm{g} \mathrm{cm}^{-}\right.$ ${ }^{3}$ )

Di $=$ Depth of $i^{\text {th }}$ layer in root zone depth $(\mathrm{cm})$

Water use efficiency $(\mathrm{kg} / \mathrm{ha} / \mathrm{cm})=\frac{Y}{W R}$

Where,

$\mathrm{Y}=$ Tuber yield $(\mathrm{kg} / \mathrm{ha})$

$\mathrm{WR}=$ Total water requirement $(\mathrm{cm})$

\section{Results and Discussion}

\section{Water Requirement}

The number, quantities of irrigation water applied, effective rainfall, soil profile contribution, total water requirement are presented in table 4 . The mean worked out data for total water requirement in respect of different irrigation levels revealed that the differences between $\mathrm{I}_{1}$ and $\mathrm{I}_{2}$ was not prominent because both these levels received two irrigation each. The small differences were due to soil profile contribution. 
Likewise, the differences in between $\mathrm{I}_{3}$ and $\mathrm{I}_{4}$ were not prominent because both $\mathrm{I}_{3}$ and $\mathrm{I}_{4}$ irrigation level received three irrigations each. These results are comparable with the finding of Banerjee and Saha, 1983 and Yadav et al.,
2003. Total water requirement worked out for $\mathrm{I}_{1}, \mathrm{I}_{2}, \mathrm{I}_{3}$ and $\mathrm{I}_{4}$ was $14.554 \mathrm{~cm}, 14.137 \mathrm{~cm}$, $19.949 \mathrm{~cm}$ and $19.826 \mathrm{~cm}$, respectively. The water requirement was almost the same due to different levels of potassium.

Table.1 Physio-chemical properties of soil of experimental plot

\begin{tabular}{|c|c|c|}
\hline Sl. No. & Particulars & Value obtained \\
\hline 1. & Sand $(\%)$ & 46.85 \\
\hline 2. & Silt $(\%)$ & 41.35 \\
\hline 3. & Clay $(\%)$ & 11.8 \\
\hline 4. & Texture & Sandy loam \\
\hline 5. & Bulk density $\left(\mathrm{g} \mathrm{cc}^{-1}\right)$ & 1.46 \\
\hline 6. & Bulk density $\left(\mathrm{g} \mathrm{cc}^{-1}\right)$ & 2.56 \\
\hline 7. & Percent pore space & 43.00 \\
\hline 8. & Water holding capacity $(\%)$ & 31.12 \\
\hline 9. & pH (1:2 Soil: water) & 8.4 \\
\hline 10. & Electrical conductivity $\left(\mathrm{dSm}^{-1}\right)$ at $25^{\circ} \mathrm{C}$ & 0.75 \\
\hline 11. & Organic carbon (\%) & 0.40 \\
\hline 12. & Available $\mathrm{N}\left(\mathrm{kg} \mathrm{ha}^{-1}\right)$ & 222.0 \\
\hline 13. & Available $\mathrm{P}_{2} \mathrm{O}_{5}\left(\mathrm{~kg} \mathrm{ha}^{-1}\right)$ & 19.0 \\
\hline 14. & Available $\mathrm{K}_{2} \mathrm{O}\left(\mathrm{kg} \mathrm{ha}^{-1}\right)$ & 117.8 \\
\hline 15. & $\mathrm{CEC}\left\{\mathrm{Cmol}(\mathrm{p}+) \mathrm{kg}^{-1}\right\}$ & 9.21 \\
\hline 16. & Free $\mathrm{CaCO}_{3}(\%)$ & 24.0 \\
\hline
\end{tabular}

Table.2 Weather condition during the crop season

\begin{tabular}{|l|c|c|c|c|c|}
\hline Month & \multicolumn{2}{|c|}{ Temperature $^{\mathbf{0}} \mathbf{C}$} & $\begin{array}{c}\text { Relative } \\
\text { Humidity (\%) } \\
\text { at 7:0 AM }\end{array}$ & $\begin{array}{c}\text { Relative } \\
\text { Humidity (\%) } \\
\text { at 2:0 PM }\end{array}$ & $\begin{array}{c}\text { Rainfall } \\
\text { (mm) }\end{array}$ \\
\hline November, 2005 & 283. & 13.7 & 86.0 & 48.0 & 0.00 \\
\hline December, 2005 & 25.0 & 9.2 & 88.0 & 43.0 & 0.00 \\
\hline January, 2006 & 21.9 & 7.8 & 90.0 & 56.0 & 0.00 \\
\hline February, 2006 & 29.7 & 14.0 & 88.0 & 51.0 & 0.00 \\
\hline
\end{tabular}

Table.3 Total amount of water applied under different treatment

\begin{tabular}{|c|c|c|c|}
\hline Treatment & IW/CPE ratio & Number of irrigation & Irrigation water applied (cm) \\
\hline $\mathbf{I}_{\mathbf{1}}$ & 0.6 & $\mathbf{2}$ & $\mathbf{1 2}$ \\
\hline $\mathbf{I}_{\mathbf{2}}$ & 0.8 & $\mathbf{2}$ & $\mathbf{1 2}$ \\
\hline $\mathbf{I}_{3}$ & 1.0 & $\mathbf{2}$ & $\mathbf{1 8}$ \\
\hline $\mathbf{I}_{\mathbf{4}}$ & 1.2 & $\mathbf{2}$ & $\mathbf{1 8}$ \\
\hline
\end{tabular}


Table.4 Total water requirement as affected by different treatments

\begin{tabular}{|c|c|c|c|c|c|c|}
\hline Treatments & $\begin{array}{l}\text { No of } \\
\text { irrigatio } \\
\quad n\end{array}$ & $\begin{array}{l}\text { Irrigatio } \\
\text { n water } \\
\text { applied } \\
\text { (cm) }\end{array}$ & $\begin{array}{l}\text { Effectiv } \\
e \\
\text { rainfall } \\
(\mathrm{cm})\end{array}$ & $\begin{array}{c}\text { Soil Profile } \\
\text { contributio } \\
\text { n }(\mathbf{c m})\end{array}$ & $\begin{array}{l}\text { Total water } \\
\text { requiremen } \\
\quad \mathrm{t}(\mathrm{cm})\end{array}$ & $\begin{array}{c}\text { WUE } \\
\text { (Kg/ha/cm) } \\
\text { based on } \\
\text { irrigation } \\
\text { water applied }\end{array}$ \\
\hline \multicolumn{7}{|l|}{ Irrigation level } \\
\hline $\mathbf{I}_{\mathbf{1}}$ (IW/CPE ratio 0.6) & 2 & 12 & 0.0 & 2.554 & 14.554 & 1216.25 \\
\hline $\mathbf{I}_{2}$ (IW/CPE ratio 0.8) & 2 & 12 & 0.0 & 2.137 & 14.137 & 1256.67 \\
\hline $\mathbf{I}_{3}$ (IW/CPE ratio 1.0) & 3 & 18 & 0.0 & 1.949 & 19.949 & 903.44 \\
\hline $\mathbf{I}_{\mathbf{4}}$ (IW/CPE ratio 1.2) & 3 & 18 & 0.0 & 1.826 & 19.826 & 940.28 \\
\hline
\end{tabular}

Table.5 Water use efficiency as affected by different treatments

\begin{tabular}{|c|c|}
\hline Treatment & Water use efficiency $(\mathrm{Kg} / \mathrm{ha} / \mathrm{cm})$ \\
\hline \multicolumn{2}{|l|}{ A. Irrigation levels } \\
\hline $\mathbf{I}_{\mathbf{1}}$ (IW/CPE ratio 0.6) & 1002.83 \\
\hline $\mathbf{I}_{2}$ (IW/CPE ratio 0.8) & 1066.69 \\
\hline $\mathbf{I}_{3}$ (IW/CPE ratio 1.0) & 815.15 \\
\hline $\mathbf{I}_{\mathbf{4}}$ (IW/CPE ratio 1.2) & 853.65 \\
\hline S. Em. \pm & 15.27 \\
\hline $\mathrm{CD}$ at $5 \%$ & 52.85 \\
\hline \multicolumn{2}{|l|}{ B. Potassium levels } \\
\hline $\mathbf{K}_{\mathbf{0}}\left(0 \mathrm{~kg} \mathrm{~K}_{2} \mathrm{O} / \mathrm{ha}\right)$ & 835.77 \\
\hline $\mathbf{K}_{1}\left(50 \mathrm{~kg} \mathrm{~K}_{2} \mathrm{O} / \mathrm{ha}\right)$ & 906.56 \\
\hline $\mathbf{K}_{\mathbf{2}}\left(100 \mathrm{~kg} \mathrm{~K}_{2} \mathrm{O} / \mathrm{ha}\right)$ & 969.76 \\
\hline $\mathbf{K}_{\mathbf{3}}\left(150 \mathrm{~kg} \mathrm{~K}_{2} \mathrm{O} / \mathrm{ha}\right)$ & 1026.24 \\
\hline S.Em. \pm & 21.42 \\
\hline $\mathrm{CD}$ at $5 \%$ & 62.52 \\
\hline \multicolumn{2}{|l|}{ Interaction $(\mathbf{I} \times \mathbf{K})$} \\
\hline S. Em. \pm & 42.84 \\
\hline $\mathrm{CD}$ at $5 \%$ & NS \\
\hline
\end{tabular}

\section{Water use - efficiency}

The water use efficiency observed under the influence of different treatments (Table 5) revealed that the difference were significant highest water use efficiency of 1066.96 $\mathrm{kg} / \mathrm{ha} / \mathrm{cm}$ was recorded under the treatment $\mathrm{I}_{2}$ receiving one irrigation after the one common irrigation followed by $I_{1}$ receiving the same number of irrigation. The lowest water use efficiency $(815.15 \mathrm{~kg} / \mathrm{ha} / \mathrm{cm})$ was noted under the treatment $\mathrm{I}_{3}$ which was at par with the treatment $\mathrm{I}_{4}(853.65 \mathrm{~kg} / \mathrm{ha} / \mathrm{cm})$. There was significant difference in water use efficiency between $\mathrm{I}_{2}$ and $\mathrm{I}_{3}$ levels of irrigation. Among the potassium levels, Significant highest water use efficiency was recorded with $\mathrm{K}_{2}$ $\left(100 \mathrm{~kg} \mathrm{~K} \mathrm{~K}_{2} \mathrm{O} / \mathrm{ha}\right)$ as compared to $\mathrm{K}_{1}(50 \mathrm{~kg}$ $\mathrm{K}_{2} \mathrm{O} / \mathrm{ha}$ ) and $\mathrm{K}_{\mathrm{O}}$ (control) but was at par with $\mathrm{K}_{3}(150 \mathrm{~kg} \mathrm{~K} \mathrm{O} / \mathrm{ha})$. Interaction effect was 
found non-significant. These results are in of confirmity of the finding of Parihar and Sandhu, 1987 and Sharma and Dixit, 1992.

The difference in water requirement was not prominent because $I_{1}$ and $I_{2}$ are receiving two irrigations where as $\mathrm{I}_{3}$ and $\mathrm{I}_{4}$ receiving three irrigation each. The water requirement was almost same due to different levels in pot Treatment $\mathrm{I}_{2}$ and $\mathrm{K}_{2}$ recorded highest water use efficiency.

\section{References}

Hsiao, T. C., 1973. Plant response to water stress. Annals Review of Plant Physiology 24: 519-570.

Hukkeri, S. B., and Sharma, A. K. 1979.Tailoring the irrigation schedule for higher plant use efficiency in potato production. Indian Journal of
Agricultural Science49:336-339.

Khalak, A., and Kumaraswamy, A.S. 1992.Dry matter accumulation and growth attributes of potato as inpluenced by irrigation and fertilizer application. Journal of Indian Potash Association 19:40-44.

Parihar, S. S., and Sadhu, B. S. 1987. Optimum irrigation schedules for crop. In: Irrigation of Field Crops- Principles and Practices ICAR publication p128.

Sharma, S. K., and Dixit, R. S. 1992. Effect of irrigation and planting techniques on tuber yield of potato. VegetableScience 3: 9-16.

Yadav, A. C., Singh. A., Barar, Jagdeep and Lal, S. 2003. Effect of irrigation and plant spacing on the growth, yield and water use efficiency of potato $c v$. Kufri Satlaj. Haryana Journal of Horticultural Science 32:138-140.

\section{How to cite this article:}

Mrityunjay Choubey, Amit Kumar Pandey and Ashutosh Singh. 2017. Influence of Different Irrigation and Potassium Levels on Water-Use-Efficiency of Potato in Calcareous Soil. Int.J.Curr.Microbiol.App.Sci. 6(9): 3107-3111. doi: https://doi.org/10.20546/ijcmas.2017.609.383 